\title{
Kanuns in Albania and Bloodfeud According to Kanun of Lekë Dukagjini
}

\author{
Gelanda Shkurtaj ${ }^{1}$
}

\begin{abstract}
In societies where it has been known and applied, bloodfeud is described as a possibly outdated and uncivilized mechanism, but often effective to limit violence. Indeed, both in form and substance the phenomenon itself is hard to be perceived and understood by the modern citizen of every country of the world, including Albania, where it is still active in some regions in respect of "Kanun". In fact, the Albanian term 'Kanun' describes the body of traditional norms/standards and rules governing society in the field of criminal, civil and procedural laws. Its application or merely its existence in moral and legal standards makes a society safer, certainly referring to a society where the power of central authority, namely of the state, either did not exist or lacked. The greatest anthropological dilemma is just there, why does Kanun work in a modern state? In societies where blood feud has been present as a regulatory element of social conflicts it is accepted that its abolition or decline occurred only when another subject (the state), took over to intervene in these conflicting relationships, and to provide the resolution and regulation of social and economic relations through enforcement of rule of law, or the public order. And the question arises by itself: why the Albanian state did not take over the blood feud solution by use of public order? The Kanun does not recognize the state or the state does not recognize the Kanun? Why? It is not easy to get into such historic and social dilemmas, but a modest effort should be made. The answer to this fact should be found by the history of Albania. As a questioning remark, the reason for the long life of Kanun, rather called as self-regulatory law of the society, is due to the historic absence of a state on the side and interests of its citizens.
\end{abstract}

Keywords: Kanun, Legal and Religious norms, Mechanic solidarity, Bloodfeud, Survival, State, Coexistence

\section{Introduction}

Dilemmas that have surrounded and continue to stir the interest of anthropologists in Albania in relation to Kanun (Gjeçovi, 1972) are focused on several aspects. They cover a wide range of issues, starting from the identification of Kanun origin, to continue with the debate whether Kanun is a law or a right and further proceed with the interpretation of norms/standards in its contents. Referring to the most illspoken, but also the most interesting aspect from anthropological and social perspective, the approach to Kanun is closely linked with its criminal/penal component, more specifically with bloodfeud and consequences it brings upon from the sanctioning point of view, according to the applicable provisions in Albania in all published or unpublished Kanuns.

Bloodfeud is a topic of equally interest and ethical and theoretical responsibility to be dealt with, since it is an already consolidated opinion that considers it only from a negative aspect, such as the one of murder (Gjeçovi, 1972). In fact, this aspect is true but 
it is not the only one characterizing it. In order to understand that, we can rely on an indepth study of the history of genesis and development in different historical stages, giving us a more concrete indication of what the people, "legislator", has wished to regulate, introducing this institute in its laws. Based on theoretical researches, of great interest is the fact that in Kanun contents the murder on grounds of bloodfeud, per se, does not constitute the "most ordinary" mechanism for conflict resolution in Kanunoriented society. Yet, it represents an extrema ratio or last recourse, after all other legal remedies are exhausted, in order to resolve the matter in conflict. The reasons of existence of Kanun and bloodfeud lie in the time-oriented and cultural context of the society where they emerged, as there was a lack of state authority, in the meaning of modern state, according to the Treaty of Westphalia (Twininig, 2003). However, historical facts of ancient and modern period in Albania, demonstrate that Kanun law has coexisted and still continues to coexist with state law and an issue of special focus is exactly the existence of Kanun at present time. This fact represents a sociological dilemma, because the Albanian state has consolidated its position as an independent state since 1912, with a body of legal, customary and religious norms, starting from the Constitution up to special laws that have regulated socio-economic relations in every aspect. At this point, the greatest dilemma arises, state law or legal and customs code, i.e. state or Kanun?

Question marks are posed in a number of areas: firstly, how is it possible that state and Kanun coexist from formal and processual point of view, without wishing to approach one another? To put it differently, in the circumstances of an issue giving rise to conflict, where must an Albanian citizen address, to the state law or to Kanun law? Secondly, why state and Kanun laws have not become a whole, as this also represents the most important issue from anthropological and sociological perspective? Thirdly, there is a slightly hidden aspect behind the formal aspect of currently occurred murders as "selfdeclaration" or "self-belief" based on Kanun, while there are facts that these murders not only are not committed under self-belief, as such in the name of Kanun, but they have nothing in common with it both from substantive and formal point of view. Fourthly, it is worth analyzing anthropologically how the state law qualifies bloodfeud, where in fact it includes it in the Criminal Code of the Republic of Albania as an alternative of murder or as a murder committed due to revenge, thus detaching it from the concept of bloodfeud as a legal institute within Kanun.

\subsection{Introduction to Kanun}

A great aid about the word etymology and hypothetically the calendar moment of Kanun emergence is provided by local authors such as Father Gjergj Fishta, as well as foreign authors. According to Father Gjergj Fishta, the word Kanun stems from the ancient Greek in the meaning of "rule", striving to correctly and strictly (Law No..7895, 2013) personify law enforcement. Further, in a general introduction of Kanun, these authors explain the title attributed to "Leka", providing also the most legitimate and commented versions by history that the association of Kanun to the name of a prince is incidental and driven or most likely affected by the strong influence it had among Lekë (a region in the Highland of Albania). However, even at this point, all referents of Kanun agree that Leka was neither the creator, nor the codifier of Kanun. An anticipatory part 
of the whole Kanun was surely the somewhat philosophical treatment of the notion of law and right as an introduction to analyze Kanun from a legal perspective. This fact, based on an analytical and comparative study, is also supported by studies of a number of anthropologists of law such as Malinowski (Malinowski, 1944) and Boasi, who have studied bloodfeud in other societies as well. In view of these objectives and outcomes, Kanun is considered as a body of legal norms/standards of a society, where the concept of law and right were integrated into a single one and the lines across this body of norms were based on principles of equality and reciprocity. Kanun among Albanians was inherited across generations based on a highly effective method, exactly the one of embracing these principles within a body of customs norms/standards, which were formally used and transmitted in daily life as customs, traditions, principles regulating their social and legal life. These norms were inherited and applied across generations only orally, still happening nowadays, notwithstanding the codification by Father Shtjefën Gjeçovi since 1913, which was not finalized due to his murder by Serbs and the conclusion of his publication via "Hylli i Dritës" newspaper, under the auspices of the giant of Albanian literature, Father Gjergj Fishta, until 1933. However, Kanun cannot be understood without a concept of bloodfeud, not only as one of vital institutions thereof, but also because Kanun and bloodfeud are still considered both sides of a coin.

\section{Kanun, a Right or a Law, a Modern or Archaic Code?}

The most substantial aspect to fairly and objectively understand and perceive Kanun has been and remains social psychology, legal approach and awareness of Kanunoriented man. One cannot pretend to know Kanun only as a body of legal norms/standards. Firstly, because it has not emerged as such and secondly, as it is commonly mentioned, one cannot know whether Kanun has previously existed in a written form. Therefore, it is believed the only proven thesis that it was written for the first time when it became a Code, only by Father Shtjefën Gjeçovi and is marked as the first and only ethnographic work converted into a Code. All legal norms/standards linked with social and economic organization and well-being of that society are permeated in their perceptive content by ethic (moral) code. Therefore, the punitive or sanctioning part underlies this Code or outlook firmly based on moral punishment. Is Kanun a legal or customs norm/standard? In case it is legal, it imposes a response about the relationship of the right/with the law, leading to the concept that every legal standard bears both social and cultural aspect of the society where it operates, and as such it cannot be seen divided from knowledge and culture, in the perception of those that know and apply Kanun.

By comparing how these norms/standards of the Albanian Kanun are approached to its counterparts in other European Codes (Castelleti, 1933), it is not a coincidence to find conceptual equality from time to time and somewhere even the superiority of our Kanun norm/standard in terms of the denial of violence and of social equality, which makes them comparable to a modern Code. Firstly, Kanun should also be judged in relation to the transition from a less civilized to a modern society. Bloodfeud, as the most personifying component of Kanun, should be viewed in the light of Weber (Weber, 1967.) and Durkheim (Durkheim, 1972) theory, wherefrom it is discovered that it was 
not merely an Albanian phenomenon, but had occurred in other countries of the world, such as in ancient Greece, Italy, Corsica, Japan and that it did not contain only its "criminal" or killing aspect, but based on the judgment of these two great scholars, it was the means, strength and law regulating social relations within communities. Both famous sociologists have different lines of reasoning on the perception and functioning of bloodfeud, but there are two aspects unifying their judgments. Firstly, because both of them do not introduce their study on the question whether bloodfeud causes the disruption or restoration of a specific social order and secondly, they share the belief that bloodfeud is, however, a social feature linked with the social order of non-modern societies. Weber compares the kin-oriented society with modern society, thus arguing that phenomenon of bloodfeud is also the most indispensable and regulatory instrument of kin-oriented society, which does not apply to modern state, where rule and social relations are based on a general ethics. According to Weber, at this point a concept of policing society has emerged (or of a society with public police order), as in this society social relations are rationalized in public domain, without leaving room to the individual or kin-oriented perception of the methods of defense or self-defense, because state is an authority unanimously operating over all subjects. Durkheim strongly supports the fact that modern societies are on one hand far from wild passions as bloodfeud and on the other hand, however, modern societies have passions beyond collective sphere and if they express themselves, they show reaction to personal interests, let say, career. This happens because a member of kin-oriented society agrees and finds his strength in the coercive power of the steering political body, firmly believing that such body will practice bloodfeud, if he suffers damage or violation (a cause for bloodfeud according to that society) from someone outside his community. Further, it is exactly the society which determines social values and applies them with sanctions punishing any violations of moral standards. From that perspective, according to Durkheim, bloodfeud is one of the multiple sanctions enabling the individual socialization in primitive societies. Accordingly, in the opinion of Durkheim, if the individual is not involved in this moral code, which is bloodfeud, he would be unworthy to live in that social group due to violation of the moral standard of that society.

\section{Bloodfeud in Kanun}

Bloodfeud in the societies where it has been known and applied, has been described as a probably outdated and non-civil but often effective mechanism to limit violence. This is so true that currently there is a belief that at ancient societies it was the main means of self-control and self-regulation of community relations. As evidenced by Kanun study, the causing leading to murders and that had to be "redeemed" by bloodfeud were based on violation of honor.

Although honor per se does not constitute one of the formal or substantial aspects of bloodfeud, it is often included and is apparently the backbone of its dynamics. Honor is not only part of human integrity in Kanun-oriented society, but through the respect of honor, alliances can be built, which in many societies, lead to a form of resistance to bloodfeud and fear thereof. Based on such predisposition, bloodfeud itself is a highly complex process with psychological burden, as well as a formal aspect of observance of 
its rule and ritual in the execution of murder, according to Kanun stipulations. In its novelty, bloodfeud has followed the principle that "bloodfeud was directed to the one who killed by a gun” (Gjeçoci, 1972), but at latter time, probably for the sake of deeply rooted phenomenon of the Albanian society, "corruption", the latter wise men expanded the circle of subjects of bloodfeud, extending it up to cradle infants. Thus, bloodfeud embraces a number of subjects that are essential for the community social and economic life, such as family, social ties and ownership matters. It is true that phenomenon per se, both for its form and content, is hard to be perceived and understood by the modern citizen of every country of the world, including Albania, as it is worth stating that bloodfeud still remains active only in some of its regions. However, its lack of understanding or knowledge would be an error if we equaled bloodfeud under Kanun and revenge on one hand and the self-declared bloodfeud on the other hand. This is stated as it is proven that many kinds of murders in Albania are attributed to bloodfeud, notwithstanding the conceptual or formal similarity with it.

Additionally, it cannot be regarded as an aspect of chaotic life. On the contrary, bloodfeud can in fact, be supposed as a notion of public order. In fact, according to the scholar Schwandner-Sievers (Schwander -Sievers, 2001), the Albanian term 'Kanun' describes the body of traditional norms/standards and concepts regulating revenge. The authorities of Albanian literature, such as Father Gjergj Fishta, but also the foreign decent scholar and Albanian history researcher Franc Nopcsa (Nopçsa, 2013. [1913],), put the Albanian Kanun into a plane similar to the Roman law, a fact showing that societies where bloodfeud was applied, did not use or see it as a tool to generate chaos, but to apply rule and law. According to a scholar such as Joel Rosenthal, bloodfeud is exactly the opposite of "chaos" (Bardhoshi, 2014). Hence, from that perspective, bloodfeud not only is not chaos, but it is rather a social mechanism to prevent the spread of violence in all aspects. The application or merely its existence within moral, legal and social norms, makes it a safer society than in cases where violence and its use against others would not be regulated, certainly referring to a society where the central body power, i.e. of the state, either did not exist or was absent. According to the ethnologist Raffaele Corso, the phenomenon of bloodfeud basically leads to two forms of social cohesion: active solidarity and passive solidarity, thus elaborating a concept very similar with Durkheim's idea between the organic and mechanical solidarity of society. The application of rule, which implies order and attributed to violence by bloodfeud, is apparently extremely weak, but it should be understood that the fundamental idea underlying revenge is exactly the application of order/rule and not of chaotic violence.

\subsection{Honour}

As often mentioned, bloodfeud is associated with the concept of honor or more specifically, it is exactly the violation of honor, which indirectly (as it commonly occurs) seeks its compensation with bloodfeud (Schwander -Sievers S. , 1999). However, in such cases not only physical harm must be indemnified by bloodfeud, but also the violation of honor of the one who has lost it, must be restored. This fact can render the bloodfeud more complex and the regulatory effect may lose. In order to restore his honor, the dishonorable man often over-reacts, therefore with his retaliation not only fails to repair it, but in fact undermines every opportunity of a balanced level of violence. Stephanie 
Schwandner-Sievers cites one of her interviewees: "If they kill one of us, we will kill 10 of them". This shows how unbalanced the calculation of violence in a bloodfeud can be. Bloodfeud in these cases becomes the problem, which was previously supposed to resolve the conflict.

\subsection{Given word}

As it is spoken about honor, the same valence in terms of violence is also the given word. This institute is one of the most sensitive ones and a supreme indicator of nature, outlook, sentiment and dedication that the Albanian has for another person in general and for the guest in particular. If the given word to a guest is violated, reciprocity in terms of violence is only bloodfeud. Without limitation thereto, based on the descriptions of Stephanie Schwandner-Sievers, violence caused by the violation of given word to the guest knows no limits or principle of "killing only the murderer". On the contrary, it should also cause more victims, because the violated honor belongs to several families, not only to the victim, but also to the host.

Not only in this case, but also generally in murder and at moments accompanying it until the first 24 hours, the institute of given word meets its legal ratio, which serves as a guarantor not only to enhance the security of family members of the murderer, but also to regulate the situation after murder (post mortem), which may degenerate in violence and mass murder.

Although there is a belief that bloodfeud has emerged to regulate a social stability, what has never prevented is paradoxically the generation of violence in another form, the one of bloodfeud until the restoration of honor or lost damage. Hence, if we accept bloodfeud as a probably ancient mechanism for the social limitation of violence, at the same time we would need to face the fact that it has also proven to be a factor of violence continuity. This is stated by both theory and practice of the judiciary and of reality, where they are properly evidenced in Albania. The concept of revenge is often transmitted across several generations, until it fully accomplishes its main objective, reciprocity and recovery. From the study of specific Kanuns, I have nowhere found a time limit, where a closing date for bloodfeud could be imagined at least hypothetically. This fact is an indicator that leaves it open for an indefinite period of time. The only one, who mentioned a statute barred of bloodfeud, is Ismet Elezi, who cites a 100 year time limit in the Kanun of Labëria (Elezi I. , 2001).

Methods to stop bloodfeud, except those already mentioned and based on reciprocity of bloodfeud or compensation with indemnification or combination thereof, are found in Kanun via the institute of "blood reconciliation" as a form of peaceful mediation concluded with blood drinking and becoming "brother" of the party in conflict. As a whole, the perspectives of modern sociologists see bloodfeud as a form of regulating and controlling violence, which loses its wholeness and importance only in societies, where there is an effective mechanism of law and law enforcement, capable to control violence. René Girard has labelled these bodies of the society as "societies policées", i.e when the control power is taken over by the state through its public order bodies, police.

\subsection{Execution in bloodfeud}

According to Kanun contents, if we see bloodfeud formally or in terms of 
execution, one is impressed by the fact that it rarely, not to say never, incorporates the element of instantaneous counteraction (Bardhoshi N. , 2014). There are rules to be applied. In honoring the victim's body, he should be turned with face in front of the sky. If the murderer does not act so, due to a number of circumstances in which he may be involved, he would ask it from the first person he encounters in the street, in order to honor the victim's body. Apart from this aspect, the norms/standards regulating the formal aspect of bloodfeud are enshrined in another group of norms/standards of moral type, of given word and honor, thus cementing the formality of bloodfeud as a rite determined in Kanun and not as a rite of ordinary or instantaneous murder (Gjeçovi A. S., 1972). What is observed and lacking in many forms of the execution of recent and present criminal subject are tortures, maltreatments, beating, leaving without meals, hanging and many other forms of extremely violent execution (Gjeçovi A. S., 1972), excluding the ritual recognized and applied by the Kanun of Labëria, cutting the nose or ears as a form of permanent discrimination of the individual in front of public opinion, borrowed by Byzantines during their influence within Albanian territories.

\subsection{Home-confinement according to Kanun}

Home-confinement as a form of application of the punitive measure, basically remains different from modern codes, because it does not apply any moral or torture punishment. Specifically, it guarantees to a certain extent, a moral and spiritual inviolability of the individual, which is punishable in this way. Accordingly, even the legal awareness of Albanian society was focused on the conservation and maintenance of this Code of Ethics, which would regulate any social relations, protecting human dignity and integrity both among living and deceased, in terms of his family, property, freedom of speech, judgment and belief. In the meantime, if home-confinement can be seen as a violent form, it may be considered as a modern method of the enforcement of criminal judgment by imprisonment. To put it right and not leave room for misunderstanding, in fact in Albania there are currently a number of facts questioning to what extent Kanun is really known and if the application of bloodfeud is merely a revenge labeled for "bloodfeud" or contains all those legal and customs components provided for and enshrined in Kanun. There is a broad and open debate, there is much to state and argue, but without wishing to focus on a counter-argument in that respect, it is almost evidenced what Kanun of Lekë Dukagjini has foreseen about bloodfeud. It is almost fully transformed and in my opinion, there is no authority such as the council of elders (wise men) to involve it once again in the ideal of social equality and reciprocity in which Kanun emerged and developed.

\subsection{Home-confinement of Children in Kanun}

In no part thereof Kanun speaks about children's home-confinement, unlike the present occurrence, where based on statistical data, the number of home-confined children is very high (Voice of America for Albania, 2018). The only element where Kanun dwells upon the child argument is in Article 969 thereof, in which it stipulates that since the moment of murder, within the next 24 hours, male family members with father-side blood ties with the murderer, must be hidden because bloodfeud in this heat wave of spiritual emotion involves even the cradle babies. However, even this aspect is 
fully unacceptable in the logics of Kanun, because a strong critical attitude is adopted when speaking about it, contained in the casteism. It states that bloodfeud applies only to the murderer, based on the principle that "bloodfeud is directed to the one who killed by a gun". However, years later it was extended to the whole blood tie, descendants, to expand the scope of objectives and therefore execution, but leaving behind a gap of legal standards/norms reflected in the fact of "endless" bloodfeud.

\section{Kanuns among Albanians and Kanun of Lekë Dukagjini}

Kanun is a summary of legal, customs and religious norms, covering a number of fields of law such as criminal, civil, family and processual ones. It is broadly spoken about Kanun, but there are few those who are informed about it. This requires first of all information about the fact that there is not only one Kanun in Albania, but in total there are seven Kanuns, some published and some others not, however known and respectable in the regions where they apply (Ombudsman:, 2016). Although customs law in Albania is not unified at a national level, based on the Kanun of Lekë Dukagjini as the most characterizing figure or Kanun par excellence in Albania, from the perspective of arrangement as a body of legal norms/standards, it has some flaws. Above all, there is a lack of chronological and logical ranking of standards, based on legal facts, however, considering the fact that they were transmitted, only verbally across centuries and without having a written basis, furthermore transcribed by Father Shtjefën Gjeçovi, who can be said that was an ethnographer, but not a legal expert, then the fact of such flawis comprehensible and justifiable. Yet, although with such apparent flaw, it is evident that Kanun contains a system of standards, either be customs-oriented, religious or legal ones, seeking to regulate the organization of a society.

In fact, it is currently observed that there is very little knowledge about Kanun, from the perspective of superficial knowledge and its wrongful interpretation (Assembly, Albanian, 2016). There are diverse underlying grounds, but they can be summed up in some key components, e.g. one factor lies in the vague interest to directly know it, as from its genesis to date (notwithstanding its publication), Kanun continues to be verbally transmitted across generations. On the other hand, there are some beliefs that have penalized it, implying they have distorted the society opinion both about the ground where Kanun emerged, imagining it as an archaic, wild and uncivilized society, and about the interpretation of norms/standards contained therein. Thirdly, even those who have studied it, including the category of ethnographers and technicians of the area, encountered mutual interpretations on Kanun, based on the reporting of two categories. On one hand, there were foreign anthropologists and on the other hand there were local ones. Regarding the local anthropologists, research is channeled to those who stated non-positive opinions, although they had a short time to live and know a reality such as the highlands of Albania, where strength and application of Kanun were highly intense and those describing it in real dimensions, making it clear, as some ambiguous dilemmas have remained, which will oblige other generations to advance and research in this area. However, at this point, citing some foreign scholars such as Nopcsa, Durham (Durham, 1990.), Valentini, Cozzi, who provided a lot of source data and have widely written about the organization of Albanian society, mainly being their genuine anthropological interest, 
they have furnished very limited data about the legal analysis such as a body of legal standards summarized in Kanun (Castelleti G. , 1940).

Though, the fact of a lack of normative-legal order favors the belief that these norms/standards are a combination of moral, legal and religious norms/standards. Here lies the secret of their survival transmitted across generations, without being lost, considering them as pillars for the organization of their social, economic and cultural life. Accordingly, they were respected more strongly in this route of transmission than if they would have been some written legal standards known only by some part of the community. Hence, they manifest the legal awareness and opinion of the Albanian society of that time, which drafted it based on the strong need to keep the community organized from all associated life perspectives (Ulqini, 2003.). Kanun is certainly an indicator of thought and psychology of Albanians at the time it was created, of the level of its mental and cultural development, although it is adapted in accordance with social changes of community in different historic stages.

\section{Bloodfeud in the Context of Modern State}

In this respect, the focus is shifted to the post-dictatorial period, thus referring to the present Kanun situation, viewed in several ways: firstly, why did Kanun survive?, secondly, to what extent does the state know Kanun, how does the state accept the relationship with it, this seen not only from sociological, but also from the juridical-legal perspective on one hand, referring to its significance and thirdly, referring to its punishment by Albanian courts.

The answer to first question, is been giving by the history of Albania. In a summary thesis, the reason for the longevity of Kanun, which would be call even as the selfregulatory law of society, lies in the historical absence of a state that has supported the interests of its citizens. It seems almost paradoxical or impossible to make such a confession, since often human logics considers the state-citizen relationship as a fatherson relationship, and the question arises whether parent wishes not to be near his child? In fact, the history of ancient Albania, at least from the year 1400 s onwards, a period to which the Kanun of Lekë Dukagjin is wrongfully attributed, Albanian Renaissance period, early nineteenth century until independence, period at the eve of Second World War, that of world war, communism, post-dictatorship and the present period have in common governments which, probably for the historical context that has not supported them, either for geopolitical context or mentalities often drawn by power temptation, have been characterized by the non-fulfilment of population interests. Hence, the Albanian, unfortunately even today, has not seen and does not see in the state a negotiator, an aide, an authority, a center of gravity and interests of all its citizens. This is the least flaw, not to mention the extremely contradictory positions the Albanian state has adopted to its subjects, especially during the period of communist dictatorship.

Then, why Kanun still lives and continues to compete with state law? The answer is rooted in the psychology of Kanun-oriented man of yesterday and today, who recognizes Kanun as the regulatory law of all relations in the social group of membership and of his lack of trust in the image of the state. It is also worth elaborating a key component in the history of rule of law and Albanian state, precisely the span of time that coincided with 
the dictatorial state, during which bloodfeud was shrank almost to extinction, though not to oblivion. As this argument has been discussed before, arguably the reasons underlying this change encompass two aspects: on one hand, the introduction of the state in all relations, mainly economic and social ones.

The dictatorial state did this for two reasons: firstly, because it wished to control everything, and secondly, because the state strictly collectivized and prohibited private property. In doing so, however, it prevented many of the underlying causes of murders and bloodfeud that would follow. As we know today, the "property" component underlies all conflicts in Albania degrading to murder. Accordingly, from the moment this component is absent, specifically because property became all state-owned, the reasons to start conflicts between people were significantly reduced. On the other hand, the Albanian state, based on the philosophy of violence and prohibition, proved too harsh with regard to Kanun: firstly, by assuming to "restore justice" through murder, i.e. the state turned into a "killer" and at the same time by imposing severe sanctions on family members of those who wanted to take revenge, often applying imprisonment or other drastic measures, thus depriving them of access to apply bloodfeud. Many killings that would have been "compensated" by bloodfeuds were reasonably left unexecuted in the dictatorial period and were executed at a time of weakened state control over this aspect.

In relation to the present state-Kanun relationship, some conclusive theses can be propounded that are somewhat hypothetical and I will explain why: firstly, bloodfeud is believed not to be known according to projections made thereon in Kanun of Lekë and in other Kanuns. Secondly, the Albanian state was indifferent to it, excluding, as mentioned above, the dictatorial state, where its aims were not to eradicate this phenomenon, rather than allow it under dictatorship of another form of government and leadership, which would go against its political interests. As for the rest, at least referring to the post-communist period, no initiatives or undertakings are heard about Kanun, firstly to fully understand and attribute its own role in the Albanian history, as well as to approach it towards an integration of economic and legal policies leading to the unification of law.

\section{Conclusions}

Frankly speaking, there is a negative opinion about Kanun in Albania, but there is a very limited number of persons, who have known, touched, read, studied or have been interested in Kanun. If this had occurred, it would have been absolutely easier to accept the judgments made thereupon, but on solid basis of study and knowledge, without wishing to add or remove any values thereof. It has to be stated, however, rather for that part of population that is unfamiliar with Kanun living also in a society we call modern and European today, that bloodfeuds are not just a phenomenon in Albania. Therefore, on the contrary, everything must be linked with Albania.

What is affected little or not at all, probably because it shows limited interest, is the truth behind Kanun. Now, we can infer some aspects of Kanun, where we can firstly state that Kanun is undated, corresponding to ancient Roman and Greek laws. Secondly, Kanun is neither primitive, nor modern, neither patriarchal, nor feudal. Modern sociology allows 
us to abolish these definitions, which state that there is no society with wide or narrow culture, that there is no more division according to the Victorian culture society, but there are simply different realities in which relationships operate and are regulated, different social norms/standards. Thirdly, it is accepted the general thesis regarding Kanun in Albania, as there were in other societies and civilizations, and it is specifically acknowledged by Kanun in Albania that the latter has a duration not present in other societies and that is still alive in a European state so close to civilization. Here is the greatest anthropological dilemma! Fourthly, it is accepted the thesis that in societies where bloodfeud has been present as a regulatory element of social relations, its waiver or exhaustion occurred only when another subject, disinterested in the parties in conflict (that is, the state) assumed to intervene with these conflicting relations and be responsible through policing (or restoration of public order) for the resolution and regulation of social and economic relations. Further, a question arises why the Albanian state has not taken it over through public order. Fifthly, state and Kanun are two rails based on two similar systems of justice but never converged to one another. Who does not know the other, Kanun or state? And why ?It is not easy to enter into such historical and social dilemmas, but a modest effort will be made.

After all, in its age-long line of logics, Kanun has a reason for existence and a community support, much stronger, than state law. Should we consider criminals all those individuals living in southern or northern Albanian only because they believe in Kanun and bloodfeuds? It is an opinion that, even though it doesn't make a distinction between murder and self-judgment as a way of restoring justice, to don't strongly prejudice an individual or community, who sees things differently from the rest of the community. It is firmly believed that, there are two options for state law and Kanun law to converge one day, leaving power, rule of law and order to the state, as many civilized countries have currently done, which yesterday had bloodfeuds as a means to maintain social order. These two paths must go in parallel and uninterruptedly until the remote day when a result can be tangible. The ways are: on one hand the state must function in an effort to build and implement an efficient system of justice within the country, whether civil or criminal one, to restore the confidence of every individual in urban and suburban areas that they can entrust their life and of their children to the state as the only authority protecting human rights.

The state must be social rather than radical, intervening with infrastructures of these areas and revitalizing lives of these communities, where poverty and fear are present in their households. On the other hand it is only education. But this cannot just come as a lesson at school! Of course, it is important, but not sufficient. Education should be introduced as a method of offering something new not related to the past, affording concrete opportunities and alternatives to a better life that sees beyond bloodfeud, as the most legitimate and absolute form of well-being in communities. It surely takes years, but if you start by removing one brick daily in this partition wall between state and Kanun, it will be invested in a near future, where poverty may not be eradicated, but the belief that bloodfeud solves everything must be faded .

Hence, police and prosecutor's office intervene with measures and reprisals. The state should demonstrate how it functions. It should firstly do it by observing law in every social area and relationship, restoring the trust of Kanun-oriented man of village or city 
that state functions. It must do it for a very long time until the consolidation of belief. This fact would certainly not suffice to prove the disappearance of bloodfeud. Yet, the constant and unchanged existence of a rule of law, associated with opening and civilization and above all with education, in a remote future would surely lead to a faded sentiment of bloodfeud as the only justice to take revenge and would believe that life is the greatest value and opportunity that God or nature has given us and should be lived to its fullest extent.

\section{References}

Gjeçovi, A. S. (1972). Kanun of "Lekë Dukagjini". Prishtinë;

Gjeçovi, A. S. (1972). Kanun of "Lekë Dukagjini". Prishtinë. GJEÇOVI, Tenth Book, "Blood”, Article 886, page.84;

Twininig, W. (2003). A post-Westphalian Conception of Law, Volume 37. Issue.1, p.199-258. Law and Society Review;

Based on Law No..7895, dated 27.01.1995, Article 78/a "Murder due to bloodfeud" (Added by Law No.. 144, dated 2.5.2013, Article 15),cites "Intentional murder due to bloodfeud shall be sentenced by not less than thirty years of imprisonment or by life imprisonment";

Malinowski, B. 1. (1944). Scientific Theory of Culture and Other Essays, Chapel Hill, N.Carolina . The University of North Carolina Press.

Castelleti, G. 1.-4. (1933). Customs Norms and Social Life in the Albanian Highlands, according to the Kanun of Lek Dukagjini.

Weber, M. (1967.). Law in Economy and Society, ed. By Max Rheinstein, trans, By Eduard Shils and Max Rheinstein. . New York: Simon and Schuster.

Durkheim, E. (1972). Selected Writings. Cambridge: Cambridge University Press. See pp.123-140.

Gjeçoci, A. S. (1972). Kanun of Lekë Dukagjini, Tenth Book, „Blood“, Article 886, Article 887,page 84. Prishtinë.

Schwander -Sievers, S. (2001). "Albanian constructions of identity, violence, power in times of crises. The enactment of "tradition": . London, Routledge.: in Bettina Schmidt\&Ingo W.Schoder's edition "Anthropology of Violence and Conflict".

Nopçsa, F. ( 2013. [1913],). Kins of the Highland of Northern Albania and their Customs Law, . Tiranë: Eneas Editions.

Bardhoshi, N. (2014). Anthropology of Kanun "Bloodfeud and social exclusion", "Cultural significance of blood", page 315. Tiranë: Center on Albanological Studies.

Schwander -Sievers, S. (1999). Humiliation and Reconciliation in Northern of Albania: . Duncker\&Humbolt/Berlin: Logics of Feuding in Symbolic and Diachronic Perspectives. Dieter Neubert's edition Dynamics .

Elezi, I. Customs Law in Labëri from a comparative plane. Tiranë, Toena. Tiranë: Toena.

Bardhoshi, Nebi. Anthropology of Kanun 2014.Chapter VI "Bloodfeud and social exclusion", "Public nature of bloodfeud", pg.317.

Gjeçoci, A. S. (1972). Kanun of Lekë Dukagjini. Eighth Book, One hundred and eighteenth Chapter, "Ambush", Article 822, pg.80.

Gjeçovi, A. S. (1972). Kanun of Lekë Dukagiini. Prishtinë: Eighth Book, One hundred and twenty first Chapter, Given Word, Article 851, pg.82.

Voice of America for Albania https:/ / www.zeriamerikes.com/ a/4435127.html

(II),O.(2016).,,On the Phenomenon of Bloodfeud in Albania”. Special Report. http://www.operazionecolomba.it/njepopullkundergjakmarrje/wpcontent/uploads/2016/03/201 6.03.04_RAPORT-I-VEÇANTË-nr.-2.1-per-gjakmarrjen.pdf.

https://www.parlament.al/wpcontent/uploads/2016/01/projekltrezoluta_per_gjakmarrjen_final_21419_1.pdf

Durham, E. (1990.). Worries of Balkans and other words for Albania and Albanians. Tiranë:: "8 Nëntori". 
Castelleti, G. (1940). Customs norms and social life in the Kanun of Lekë Dukagjini. Ombra GVG. Fq.7, foreword of page 7 cites Salvatore VILARI, Le consuetudini giuridiche dell'Albania: foreword, page 5: "It is generally about observations, eit. Rome.

Ulqini, K. (2003.). Structure of the Albanian traditional society: Mountains of Dibra; Kanun laws of Himara, Bayraks; Suliotbond, family communities of Mat. Shkodër: Idromeno. 